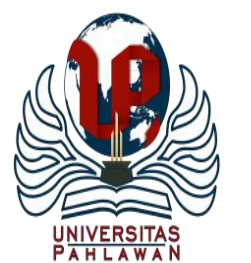

Edukatif : Jurnal Ilmu Pendidikan Volume 3 Nomor 2 Tahun 2021 Halm 436 - 446 EDUKATIF: JURNAL ILMU PENDIDIKAN

Research \& Learning in Education

https://edukatif.org/index.php/edukatif/index

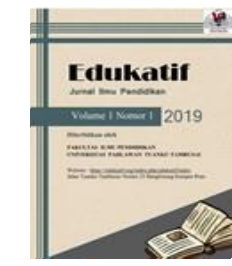

\title{
Meta Analisis Model Pembelajaran Kooperatif Tipe Numbered Head Together Terhadap Hasil Belajar Siswa di Sekolah Dasar
}

\author{
Agape Purwa Gracia ${ }^{1 凶}$, Indri Anugraheni ${ }^{2}$ \\ Pendidikan Guru Sekolah Dasar. Universitas Kristen Satya Wacana ${ }^{1,2}$ \\ E-mail : agapepurwa32@gmail.com $^{1}$, indri.anugraheni@uksw.edu ${ }^{2}$
}

\begin{abstract}
Abstrak
Penelitian ini dilakukan dengan tujuan menganalisis kembali penggunaan model pembelajaran kooperatif tipe Numbered Head Together terhadap hasil belajar siswa sekolah dasar. Penelitian menggunakan metode meta analisis. Perumusan masalah dimulai pada awal penelitian, kemudian dilanjutkan dengan menguji hasil penelitian yang relevan. Pengumpulan data berupa artikel dan jurnal elektronik dilakukan dengan bantuan Google Scholar. Hasil pencarian diperoleh sebanyak 12 artikel relevan, jurnal elektronik dan essai. Teknik analisis data yang digunakan dalam penelitian ini yaitu dengan menggunakan uji normalitas, setelah uji normalitas maka berlanjut pada uji paired samples test, dan dilakukan penghitungan effect size untuk mengetahui seberapa besarnya pengaruh penggunaan model pembelajaran kooperatif tipe Numbered Head Together terhadap hasil belajar siswa sekolah dasar. Analisis data dilakukan dengan bantuan SPSS 25 for windows. Hasil dari analisis data yang telah dilakukan menunjukan bahwa model pembelajaran kooperatif tipe Numbered Head Together berpengaruh besar terhadap hasil belajar siswa dari yang terendah 7,13\% sampai yang tertinggi $91,87 \%$ dengan nilai rata-rata $37,11 \%$, hasil penghitungan effect size diperoleh sebesar 1,91 maka dapat disimpulkan pengaruh penggunaan model pembelajaran kooperatif tipe Numbered Head Together terhadap hasil belajar siswa sekolah dasar termasuk dalam kategori besar.
\end{abstract}

Kata Kunci : Numbered Head Together, Hasil Belajar, Meta Analisis.

\begin{abstract}
This study was conducted with the aim of reanalyzing the use of cooperative learning model type Numbered Head Together to the learning outcomes of elementary school students. Research using meta analysis method. The formulation of the problem begins at the beginning of the study, then continues by testing the relevant research results. Data collection in the form of articles, electronic journals, and essays is done with the help of Google Scholar. Search results obtained as many as 12 relevant articles, electronic journals and essays. The data analysis technique used in this study is to use the normality test, after the normality test then continued on the paired samples test, and the calculation of effect size to find out how much influence the use of cooperative learning model type Numbered Head Together on the learning outcomes of elementary school students. Data analysis is done with the help of SPSS 25 for windows. The results of the data analysis that has been done show that the cooperative learning model type Numbered Head Together has a big effect on student learning outcomes from the lowest $7.13 \%$ to the highest $91.87 \%$ with an average score of $37,11 \%$, the results of the calculation of effect size obtained by 1.19 then it can be concluded the influence of the use of cooperative learning models type Numbered Head Together on the results of elementary school students are included in the large category.
\end{abstract}

Keywords : Numbered Head Together, Learning Outcomes, Meta Analysis.

Copyright (c) 2021 Agape Purwa Gracia, Indri Anugraheni

$\triangle$ Corresponding author

Email : agapepurwa32@gmail.com

DOI : https://doi.org/10.31004/edukatif.v3i2.338

ISSN 2656-8063 (Media Cetak)

ISSN 2656-8071 (Media Online)

Edukatif : Jurnal Ilmu Pendidikan Vol 3 No 2 Tahun 2021 p-ISSN 2656-8063 e-ISSN 2656-8071 


\section{PENDAHULUAN}

Pendidikan merupakan suatu media yang dapat membentuk karakter seseorang menjadi lebih berpotensi dan berkualitas, sehingga dengan adanya pendidikan manusia akan mengalami proses pendewasaan diri dalam pengambilan keputusan masalah yang dihadapi disertai rasa tanggung jawab yang besar. Indonesia merupakan salah satu negara yang mendukung perkembangan pendidikan masyarakatnya sebagaimana dijabarkan dalam Undang-Undang Nomor 20 Tahun 2003 tentang Sistem Pendidikan Nasional pada Bab 1 Pasal 1 Ayat 1 "Pendidikan adalah usaha sadar dan terencana untuk mewujudkan suasana belajar dan proses pembelajaran agar peserta didik secara aktif mengembangkan potensi dirinya". Untuk mencapai hasil pendidikan seperti yang diharapkan dalam undang-undang maka diperlukan adanya proses pembelajaran yang dapat membentuk siswa berkarakter, bertakwa, mandiri serta dapat berperan aktif dalam pembangunan bangsa. Sugihartono dalam (Kirom, 2017:70) berpendapat bahwa proses pembelajaran adalah upaya yang dilakukan oleh pendidik atau guru dengan cara sengaja yang bertujuan untuk menyampaikan ilmu pengetahuan dengan cara mengorganisasikan serta membentuk sistem lingkungan belajar dengan bermacam-macam metode sehingga siswa bisa melakukan kegiatan belajar dengan maksimal. Salah satu tempat yang dapat mendukung proses pembelajaran dengan situasi yang mendukung adalah lingkungan sekolah. Lingkungan sekolah sebagai lingkungan formal memiliki beberapa jenjang yaitu jenjang pendidikan dasar, pendidikan menengah dan pendidikan tinggi. Pendidikan pada jenjang sekolah dasar merupakan hal yang sangat penting karena pendidikan pada jenjang ini akan menunjang keberhasilan peserta didik pada jenjang berikutnya.

Salah satu muatan pembelajaran yang diajarkan pada sekolah dasar adalah matematika dan Ilmu Pengetahuan Sosial (IPS). Matematika adalah salah satu bidang studi yang berguna untuk membantu menyelesaikan masalah dalam kehidupan sehari-hari dan dapat meningkatkan kemampuan berpikir dan berargumentasi (Susanto, 2013:148). Ilmu Pengetahuan Sosial adalah pembelajaran yang mengajarkan tentang kehidupan sosial manusia yang berkaitan tentang kegiatan-kegiatan manusia untuk memenuhi kebutuhan hidupnya serta lembaga yang dikembangkan manusia (Solihatin, 2008:15). Dari pernyataan ahli diatas maka dapat disimpulkan bahwa matematika dan IPS merupakan muatan pembelajaran yang penting bagi siswa sekolah dasar karena kedua muatan pembelajaran ini dapat membangun cara berpikir mereka untuk menyelesaikan masalah dalam kehidupan sehari-hari dan dapat digunakan dalam kehidupan bermasyarakat nantinya. Proses pembelajaran bisa dikatakan berhasil jika siswa memperoleh hasil belajar secara maksimal. Hasil belajar adalah pencapaian bentuk dari perubahan perilaku dari aspek kognitif, afektif, dan psikomotoris dari proses belajar yang dilakukan dalam jangka waktu tertentu (Jihad, 2012:14), sejalan dengan pengertian sebelumnya Popi Radyuli (2019) menyatakan pendapat bahwa hasil belajar merupakan perubahan tingkah laku yang terjadi pada seseorang yang dapat diamati dan diukur dalam bentuk pengetahuan, sikap dan keterampilan. Hasil belajar merupakan hasil perubahan perilaku peserta didik setelah melaksanakan kegiatan belajar mengajar (Hanggara, 2016:82). Hasil Belajar juga merupakan hasil penilaian terhadap kemampuan siswa yang dinyatakan dalam bentuk angka yang diperoleh siswa dari serangkaian tes maupun ujian akhir yang diberikan oleh guru setelah melalui proses pembelajaran (Wasti, 2013:3). Ada beberapa faktor yang dapat mempengaruhi hasil belajar 1) faktor internal, merupakan faktor yang berasal dari diri sendiri, meliputi faktor fisiologis dan psikologi, 2) faktor eksternal, yaitu faktor yang berasal dari luar, meliputi faktor sosial dan non sosial (Suryabrata, 2010:235). Dari pendapat diatas maka dapat disimpulkan dari beberapa pendapat diatas maka dapat disimpulkan hasil belajar adalah pencapaian yang diperoleh siswa dari aspek kognitif, afektif, dan psikomotorik siswa setelah melalui proses pembelajaran yang dipengaruhi oleh faktor internal dan eksternal.

Model pembelajaran yang dipilih oleh guru menjadi salah satu sumber yang berkaitan dengan faktorfaktor lainnya. Model pembelajaran adalah pola atau rancangan yang digunakan dalam merencanakan suatu pembelajaran di kelas (Trianto, 2010:52), kerangka konseptual yang mengatur proses belajar siswa secara 
teratur dan sistematis untuk mengelola pengalaman belajar siswa dan untuk mencapai tujuan belajar yang diinginkan juga disebut sebagai model pembelajaran (Suprihatiningrum, 2013:145), model pembelajaran hakikatnya menggambarkan keseluruhan yang terjadi dalam pembelajaran dari awal pembelajaran, saat pembelajaran, maupun akhir pembelajaran tidak hanya pada guru namun juga siswa (Sundari, 2015:109), berdasarkan beberapa pernyataan para ahli diatas maka pemilihan model pembelajaran oleh guru harus tepat supaya tercapainya hasil belajar yang maksimal. Dengan memilih model pembelajaran yang tepat proses pembelajaran akan lebih menyenangkan bagi siswa serta dapat meningkatkan kreativitas siswa dan dapat memudahkan siswa dalam menerima materi. Cooperative learning (pembelajaran kooperatif) merupakan salah satu model pembelajaran yang dapat membuat siswa aktif selama proses belajar dilakukan. Hamdayana (2016:132) berpendapat bahwa model pembelajaran kooperatif dilakukan siswa dalam kelompok-kelompok kecil yang beranggotakan empat sampai enam orang siswa, kelompok-kelompok kecil ini dibentuk dengan tujuan dapat mencapai tujuan pembelajaran yang telah ditetapkan dengan cara siswa bekerjasama dengan siswa yang lain. Pembelajaran kooperatif merupakan metode belajar yang dilakukan dengan cara bekerja sama antar siswa, sehingga siswa tidak semata mencapai kesuksesan secara individual atau saling mengalahkan antar siswa, namun mereka juga dapat membantu teman belajarnya yang memiliki kemampuan dibawah standar minimum (Rofiq, 2010:1). Model pembelajaran kooperatif bukan hanya belajar secara berkelompok, ada beberapa unsur yang membedakan pembagian kelompok secara asal-asalan, unsur dasar dalam pembelajaran kooperatif yaitu ketergantungan positif, komunikasi antar anggota kelompok, tanggung jawab masing-masing anggota, tatap muka, dan evaluasi proses kelompok. Pada pembelajaran kooperatif siswa memiliki kesempatan berkomunikasi serta dapat berinteraksi secara sosial, artinya pada proses pembelajaran siswa dituntut untuk aktif dan bertanggung jawab atas hasil pembelajaran yang sedang berlangsung (Isjoni, 2009:5).

Numbered Head Together (NHT) adalah salah satu tipe pembelajaran kooperatif, model pembelajaran ini bertujuan untuk meningkatkan penguasaan akademik siswa dan meningkatkan interaksi antar siswa (Santiana, 2014:3), model pembelajaran kooperatif tipe Numbered Head Together (NHT) menekankan struktur khusus yang dirancang untuk mempengaruhi pola interaksi siswa dan memiliki tujuan untuk meningkatkan penguasaan akademik. Huda (2013:38) berpendapat bahwa model pembelajaran kooperatif tipe Numbered Head Together (NHT) dirancang untuk memberikan kesempatan kepada siswa untuk saling bertukar ide-ide dan mempertimbangkan jawaban yang tepat dari pertanyaan maupun pernyataan yang diberikan oleh guru. Pembelajaran kooperatif tipe Numbered Head Together ini merupakan salah satu model pembelajaran yang memberikan kesempatan kepada siswa untuk saling berbagi ide-ide dan mempertimbangkan jawaban yang paling tepat serta dirancang untuk mempengaruhi pola interaksi siswa dan sebagai alternatif terhadap struktur kelas tradisional (Kristian, 2018:74). Berdasarkan beberapa pernyataan diatas dapat disimpulkan bahwa model pembelajaran kooperatif tipe Numbered Head Together merupakan model pembelajaran yang memberikan kesempatan kepada siswa untuk saling bertukar ide antar siswa dalam kelompoknya masing-masing serta mempertimbangkan jawaban yang paling tepat dan bertujuan untuk meningkatkan penguasaan akademik dan interaksi siswa. Adapun langkah-langkah dalam model pembelajaran kooperatif tipe Numbered Head Together, menurut Huda (2013:203-204) terdapat lima langkah untuk melakukan model pembelajaran kooperatif tipe Numbered Head Together, yaitu : 1) siswa dibentuk dalam kelompok yang beranggotakan empat sampai enam orang siswa, 2) setiap siswa yang sudah berada dalam kelompok diberi nomor, 3) masing-masing kelompok yang sudah dibentuk mendapatkan tugas atau pertanyaan dari guru, 4) setiap kelompok yang sudah diberi tugas atau pertanyaan oleh guru, maka anggota yang berada dalam kelompok tersebut bisa saling berdiskusi untuk menemukan jawaban yang paling tepat dan memastikan semua anggota kelompok mengetahui jawaban tersebut, 5) setelah berdiskusi dan mendapat jawaban yang menurut setiap kelompok benar, guru memanggil salah satu nomor secara acak dan siswa dengan nomor yang dipanggil dapat mempresentasikan jawaban dari kelompoknya. Kelebihan pembelajaran 
kooperatif tipe Numbered Head Together yaitu : 1) mampu memperdalam pemahaman siswa, 2) melatih tanggung jawab siswa, 3) mengembangkan rasa ingin tahu siswa, 4) meningkatkan rasa percaya diri siswa, 5) menyenangkan siswa dalam belajar (Mahardika, 2018:3). Berdasarkan uraian diatas dapat ditarik kesimpulan dengan proses pembelajaran yang demikian siswa merasa senang dan tidak merasa bosan saat pembelajaran berlangsung, dikarenakan setiap siswa dapat berperan aktif dalam kelompoknya masing-masing, dengan digunakannya model pembelajaran kooperatif tipe Numbered Head Together dalam kegiatan pembelajaran maka dapat mempengaruhi hasil belajar siswa.

Banyak penggunaan model pembelajaran kooperatif tipe Numbered Head Together yang dapat mempengaruhi hasil belajar siswa. Sudah banyak hasil penelitian yang membuktikan bahwa dengan menggunakan model pembelajaran kooperatif tipe Numbered Head Together berpengaruh terhadap hasil belajar siswa. Penelitian yang dilakukan oleh I Md. Oka Susila, I Wyn. Rinda Suardika, (2015) dengan judul "Model Pembelajaran Kooperatif Tipe NHT Berbantuan Media Konkret Berpengaruh Terhadap Hasil Belajar Matematika Siswa Kelas V SD Gugus VII Kecamatan Gianyar" membuktikan bahwa terdapat perbedaan signifikan terhadap hasil belajar matematika ketika siswa belajar menggunakan model pembelajaran kooperatif tipe Numbered Head Together dengan siswa belajar menggunakan model pembelajaran konvensional, jadi dapat disimpulkan model pembelajaran kooperatif tipe Numbered Head Together berpengaruh pada hasil belajar siswa sekolah dasar, sejalan dengan hasil penelitian di atas penelitian yang telah dilakukan oleh Desy Nilam Sari, Suyitno Suyitno, (2018) yang berjudul "Keefektifan Model Number Head Toghether Terhadap Hasil Belajar IPS Kelas III SD Negeri Danyangmulyo 02 Kabupaten Pati" mendapatkan hasil penelitian bahwa model pembelajaran kooperatif tipe Numbered Head Together berpengaruh untuk meningkatkan hasil belajar siswa sekolah dasar. Berdasarkan uraian dan hasil penelitian terdahulu belum terdapat penelitian meta-analisis, maka penelitian ini bertujuan untuk mengetahui pengaruh penggunaan model pembelajaran kooperatif tipe Numbered Head Together terhadap hasil belajar siswa menggunakan metode penelitian meta-analisis.

\section{METODE PENELITIAN}

Pengumpulan data diperoleh dari artikel, jurnal elektronik dan esai yang dicari menggunakan bantuan google scholar dengan menggunakan kata kunci "Numbered Head Together", "Pembelajaran Kooperatif" dan "Hasil Belajar". Hasil penelusuran mendapatkan 12 artikel, jurnal elektronik dan esai yang relevan dan sudah diterbitkan. Analisis data dilakukan dengan cara membandingkan selisih nilai sebelum model pembelajaran kooperatif tipe Numbered Head Together dilakukan dengan nilai sesudah model pembelajaran kooperatif tipe Numbered Head Together dilakukan. Kemudian nilai yang diperoleh dari nilai selisih itu dibagi dengan nilai sebelum diterapkannya model pembelajaran Numbered Head Together (dalam bentuk \%) untuk mengetahui persentase besarnya pengaruh model pembelajaran kooperatif tipe Numbered Head Together terhadap hasil belajar siswa.

\section{HASIL DAN PEMBAHASAN PENELITIAN}

Dari hasil pencarian data diperoleh hasil 12 artikel, jurnal elektronik dan esai yang terkait dengan pengaruh model pembelajaran kooperatif tipe Numbered Head Together terhadap hasil belajar siswa sekolah dasar. Kemudian 12 data yang diperoleh diolah kembali dengan cara dirangkum dan diberi kode (A) yang berarti artikel kemudian dilaporkan kembali menggunakan cara deskriptif kualitatif dan kuantitatif. Berikut data dari hasil analisis model pembelajaran kooperatif tipe Numbered Head Together : 
440 Meta Analisis Model Pembelajaran Kooperatif Tipe Numbered Head Together Terhadap Hasil Belajar Siswa di Sekolah Dasar - Agape Purwa Gracia, Indri Anugraheni

DOI: https://doi.org/10.31004/edukatif.v3i2.338

Tabel 1. Hasil Analisis Model Pembelajaran Kooperatif Tipe Numbered Head Together Terhadap Hasil Belajar Siswa Sekolah Dasar

\begin{tabular}{|l|c|c|c|c|c|}
\hline \multirow{2}{*}{ No } & \multirow{2}{*}{$\begin{array}{c}\text { Kode } \\
\text { Data }\end{array}$} & & \multicolumn{4}{|c|}{ Pengaruh Hasil Belajar } \\
\cline { 3 - 6 } & & $\begin{array}{c}\text { Pre } \\
\text { test }\end{array}$ & $\begin{array}{c}\text { Post } \\
\text { Test }\end{array}$ & Gain & Gain\% \\
\hline 1. & A1 & 33,25 & 63,8 & 30,55 & 91,87 \\
\hline 2. & A2 & 75,56 & 86,13 & 10,57 & 13,98 \\
\hline 3. & A3 & 57,78 & 81,23 & 23,45 & 40,58 \\
\hline 4. & A4 & 63,62 & 77,06 & 13,44 & 21,12 \\
\hline 5. & A5 & 75,33 & 84,52 & 9,19 & 12,19 \\
\hline 6. & A6 & 54,48 & 89,31 & 34,83 & 63,93 \\
\hline 7. & A7 & 55,49 & 84,83 & 29,34 & 52,87 \\
\hline 8. & A8 & 74,67 & 80,00 & 5,33 & 7,13 \\
\hline 9. & A9 & 67,35 & 83,58 & 16,23 & 24,09 \\
\hline 10. & A10 & 53,60 & 65,58 & 11,98 & 22,35 \\
\hline 11. & A11 & 64,05 & 81,85 & 17,8 & 27,79 \\
\hline 12. & A12 & 54,80 & 91,80 & 37,00 & 67,51 \\
\hline \multicolumn{2}{|r|}{ Rata-Rata } & 60,83 & 80,80 & 19,97 & 37,11 \\
\hline
\end{tabular}

Hasil dari analisis data dari 12 jurnal, pada tabel 1 dapat dilihat penggunaan model pembelajaran kooperatif tipe Numbered Head Together berpengaruh terhadap peningkatan hasil belajar matematika dan IPS siswa sekolah dasar. Persentase peningkatan hasil belajar siswa dengan menggunakan model pembelajaran kooperatif Numbered Head Together dari yang terendah 7,13\% dan yang tertinggi 91,87\% dengan rata-rata sebesar $37,11 \%$. Nilai rata-rata sebelum menggunakan model pembelajaran kooperatif tipe Numbered Head Together yaitu $53,60 \%$ kemudian nilai rata-rata mengalami peningkatan yang signifikan sesudah menggunakan model pembelajaran kooperatif tipe Numbered Head Together yaitu sebesar 80,80\%. Setelah itu dilakukan uji normalitas sebagai uji prasyarat untuk melakukan uji Paired Sample Test. Berikut hasil dari uji normalitas :

Tabel 2. Uji Normalitas Model Pembelajaran Kooperatif Numbered Head Together

\begin{tabular}{|c|c|c|c|c|c|c|}
\hline \multicolumn{7}{|c|}{ Tests of Normality } \\
\hline & \multicolumn{3}{|c|}{ Kolmogorov-Smirnov ${ }^{\mathrm{a}}$} & \multicolumn{3}{|c|}{ Shapiro-Wilk } \\
\hline & Statistic & $\mathrm{df}$ & Sig. & Statistic & $\mathrm{df}$ & Sig. \\
\hline PRE TEST & .191 & 12 & $200^{*}$ & .903 & 12 & 172 \\
\hline POST TEST & .212 & 12 & .142 & .880 & 12 & .088 \\
\hline
\end{tabular}

Tabel 2 menunjukan bahwa hasil uji normalitas pretest dan posttest model pembelajaran kooperatif tipe Numbered Head Together terhadap hasil belajar siswa sekolah dasar. Uji normalitas menggunakan data Shapiro-wilk dengan bantuan spss 25 for windows, nilai signifikansi dari pretest $0,172>0,05$, begitu juga dengan nilai signifikansi dari posttest yaitu $0,88>0,05$, dengan ini dapat disimpulkan bahwa data berdistribusi normal. Berikut adalah hasil uji Paired Sample Test : 
441 Meta Analisis Model Pembelajaran Kooperatif Tipe Numbered Head Together Terhadap Hasil Belajar Siswa di Sekolah Dasar - Agape Purwa Gracia, Indri Anugraheni

DOI: https://doi.org/10.31004/edukatif.v3i2.338

Tabel 3. Paired Samples Statistics (Statistik Sampel Berpasangan)

\begin{tabular}{|c|c|c|c|c|c|}
\hline \multicolumn{6}{|c|}{ Paired Samples Statistics } \\
\hline & & Mean & $\mathrm{N}$ & Std. Deviation & $\begin{array}{l}\text { Std. Error } \\
\text { Mean }\end{array}$ \\
\hline \multirow[t]{2}{*}{ Pair 1} & PRE TEST & 60.8317 & 12 & 12.08629 & 3.48901 \\
\hline & POST TEST & 80.8075 & 12 & 8.50775 & 2.45598 \\
\hline
\end{tabular}

Berdasarkan hasil tabel 3 paired samples statistics penggunaan model pembelajaran kooperatif tipe Numbered Head Together berpengaruh terhadap peningkatan hasil belajar siswa sekolah dasar dengan nilai rata-rata 60,8317 menjadi 80,8075, dengan ini peningkatan nilai rata-rata dari dilaksanakannya pretest dan posttest yaitu 19,9758.

Tabel 4. Paired Samples Correlations (Korelasi Sampel Berpasangan)

\begin{tabular}{|l|l|r|r|c|}
\hline \multicolumn{6}{|c|}{ Paired Samples Correlations } \\
\hline Pair 1 & $\begin{array}{l}\text { PRE TEST \& POST } \\
\text { TEST }\end{array}$ & 12 & .502 & .096 \\
\hline
\end{tabular}

Berdasarkan tabel 4 nilai Sig. diperoleh hasil 0,096>0,05, maka dapat disimpulkan bahwa tidak terdapat hubungan antara variabel pretest dan posttest dikarenakan $>0,05$.

Tabel 5. Paired Samples Test (Uji Sampel Berpasangan)

\begin{tabular}{|c|c|c|c|c|c|c|c|c|c|}
\hline \multicolumn{10}{|c|}{ Paired Samples Test } \\
\hline & & \multicolumn{5}{|c|}{ Paired Differences } & \multirow[b]{3}{*}{$\mathrm{t}$} & \multirow[b]{3}{*}{ df } & \multirow{3}{*}{$\begin{array}{l}\text { Sig. } \\
(2- \\
\text { tailed) }\end{array}$} \\
\hline & & \multirow[b]{2}{*}{ Mean } & \multirow{2}{*}{$\begin{array}{c}\text { Std. } \\
\text { Deviatio } \\
\mathrm{n}\end{array}$} & \multirow{2}{*}{$\begin{array}{l}\text { Std. } \\
\text { Error } \\
\text { Mean }\end{array}$} & \multicolumn{2}{|c|}{$\begin{array}{l}95 \% \text { Confidence } \\
\text { Interval of the } \\
\text { Difference }\end{array}$} & & & \\
\hline & & & & & Lower & Upper & & & \\
\hline Pair 1 & \begin{tabular}{|l} 
PRE \\
TEST \\
- \\
POST \\
TEST
\end{tabular} & 19.97583 & 10.73126 & 3.09785 & 26.79415 & $\begin{array}{r}13.15752 \\
-\end{array}$ & -6.448 & 11 & .000 \\
\hline
\end{tabular}

Pada tabel 5 menunjukan hasil Sig. (2-tailed) 0,00 yang berarti lebih kecil dari 0,05 $(0,00<0,05)$ hasil ini menunjukan bahwa $\mathrm{H}_{0}$ ditolak dan $\mathrm{H}_{1}$ diterima, hasil $\mathrm{t}_{\text {hitung }}$ sebesar $-6,448$ dan memperoleh $\mathrm{t}_{\text {tabel }}$ sebesar 1,796, $t_{\text {tabel }}$ diperoleh dari tabel $t$ dimana tabel tersebut berisikan angka-angka titik presentase distribusi df dan taraf signifikan, maka dapat disimpulkan berdasarkan hasil analisis data dari proses penghitungan yang sudah dilakukan menunjukan adanya perbedaan yang signifikan terhadap hasil belajar siswa sekolah dasar sebelum dan sesudah menggunakan model pembelajaran kooperatif Numbered Head Together.

Besarnya pengaruh penggunaan model pembelajaran kooperatif tipe Numbered Head Together terhadap hasil belajar siswa sekolah dasar dapat menggunakan effect size. Dibawah ini merupakan interpretasi effect size menurut Cohen's d : 
442 Meta Analisis Model Pembelajaran Kooperatif Tipe Numbered Head Together Terhadap Hasil Belajar Siswa di Sekolah Dasar - Agape Purwa Gracia, Indri Anugraheni

DOI: https://doi.org/10.31004/edukatif.v3i2.338

Tabel 6. Interpretasi Effect Size Cohen's d

\begin{tabular}{|c|c|}
\hline Batasan & Kategori \\
\hline $0-0,2$ & Kecil \\
\hline $0,2-0,5$ & Sedang \\
\hline $0,5-0,8$ & Besar \\
\hline $\mathrm{d}>0,8$ & Sangat Besar \\
\hline
\end{tabular}

Hasil penghitungan yang telah dilakukan oleh peneliti dan dapat dilihat pada tabel 3 nilai saat pretest mendapatkan nilai rata-rata sebesar 60,8317 dengan standard deviation sebesar 12,08629, sesudah dilakukannya posttest mengalami peningkatan signifikan dengan nilai sebesar 80,808075 dengan standard deviation sebesar 8,50775. Berikut rumus penghitungan effect size berdasarkan Cohen's d :

$$
d=\frac{M_{\text {posttest }}-M_{\text {pretest }}}{\sqrt{\frac{\left(S D_{\text {pretest }}^{2}+S D_{\text {posttest }}^{2}\right)}{2}}}
$$

\section{Keterangan:}

D

$M_{\text {pretest }}$

$M_{\text {posttest }}$

$\mathrm{SD}_{\text {pretest }}$

$\mathrm{SD}_{\text {posttest }}$
$=$ Effect Size

$=$ mean pretest

$=$ mean posttest

= standard deviation pretest

$=$ standard deviation posttest

Dari hasil penghitungan yang dilakukan oleh peneliti menggunakan rumus effect size diatas, maka akan diperoleh hasil seperti data dalam tabel interpretasi effect size, dapat dilihat pada tabel 6. Berikut hasil penghitungan yang telah dilakukan oleh peneliti menggunakan rumus diatas :

$$
\begin{aligned}
& d=\frac{M_{\text {posttest }}-M_{\text {pretest }}}{\sqrt{\frac{\left(S D_{\text {pretest }}{ }^{2}+S D_{\text {posttest }}{ }^{2}\right)}{2}}} \\
& d=\frac{\frac{80,8075-60,8317}{\sqrt{\frac{\left(12,08629^{2}+8,50775^{2}\right)}{2}}}}{\sqrt{\frac{146,0784059641+72,3818100625}{2}}}
\end{aligned}
$$




$$
\begin{aligned}
& d=\frac{19,9758}{\sqrt{\frac{218,4602157566}{2}}} \\
& d=\frac{19,9758}{\sqrt{109,2301078783}} \\
& d=\frac{19,9758}{10,4513208676} \\
& d=1,9113182203 \\
& d=1,91
\end{aligned}
$$

Hasil Penghitungan effect size yang dilakukan oleh peneliti mendapatkan hasil sebesar 1,91. Diketahui dari nilai $\mathrm{d}=1,91$ lebih besar dari $0,8(1,91>0,8)$ bila dilihat dari tabel interpretasi effect size hasil analisis data yang didapatkan termasuk dalam kategori sangat tinggi, maka dengan menggunakan model pembelajaran kooperatif tipe Numbered Head Together memiliki pengaruh positif yang sangat tinggi terhadap peningkatan hasil belajar siswa sekolah dasar. Hasil analisis data ini dapat disimpulkan bahwa pembelajaran dengan menggunakan model kooperatif tipe Numbered Head Together berpengaruh sangat tinggi pada peningkatan hasil belajar siswa.

Dalam proses pembelajaran model pembelajaran yang dipilih oleh guru sangat berpengaruh pada hasil akhir yang akan dicapai oleh siswa, salah satu model pembelajaran yang dapat digunakan oleh guru adalah model pembelajaran kooperatif tipe Numbered Head Together, dengan menggunakan model pembelajaran ini maka setiap siswa yang berada di kelas dituntut untuk melakukan aktivitas, seperti saling bertukar ide untuk menemukan jawaban yang paling tepat dalam kelompok dan memaparkan jawaban yang sudah disepakati dalam kelompok tersebut, dengan ini siswa tidak akan cepat bosan dan jenuh selama proses pembelajaran berlangsung karena mereka bekerja dalam kelompok sehingga interaksi yang dilakukan dengan temannya akan terasa menyenangkan bagi siswa. Sesuai dengan pendapat Fatima Batubara dan Karya Sinulingga (2014:53) yang menyatakan bahwa penggunaan model pembelajaran kooperatif tipe Numbered Head Together mempunyai pengaruh yang sangat positif karena dalam pembelajaran peserta didik diberikan kesempatan untuk saling bertukar ide, dengan begitu siswa akan mendapatkan pengetahuan yang lebih baik serta setiap peserta didik akan saling membantu satu sama lain, tidak hanya bertukar ide peserta didik juga akan menentukan jawaban yang paling tepat dalam kelompoknya, sehingga dalam hal ini akan menumbuhkan rasa tanggung jawab yang dimiliki oleh peserta didik. Pendapat ini didukung dengan temuan penelitian yang dilakukan oleh Vivi Muliandari (2019) dalam penggunaan pembelajaran kooperatif tipe Numbered Head Together peserta didik secara langsung dapat memecahkan masalah, memahami materi secara berkelompok dan dapat membantu satu satu dengan yang lainnya, ,membuat kesimpulan dan mempresentasikan didepan kelas sebagai evaluasi untuk kegiatan pembelajaran yang telah dilaksanakan, keaktifan siswa dalam kegiatan pembelajaran dengan menggunakan model pembelajaran kooperatif tipe Numbered Head Together membuktikan berpengaruh terhadap peningkatan hasil belajar siswa, karena selama proses pembelajaran siswa menganggap kegiatan pembelajaran yang melibatkan siswa secara langsung akan menjadi lebih menarik dan siswa lebih bersemangat saat mengikuti pembelajaran, hal ini akan mendorong siswa lebih mudah masuk kedalam zona nyaman untuk belajar di kelas.

Hasil dari penelitian ini sejalan dengan penelitian yang dilakukan oleh Afif Akhmad Rizki (2016) dengan judul penelitian "Keefektifan Model Numbered Head Together Berbantuan Macromedia Flash Dalam Pembelajaran IPS Siswa Kelas IV SDN Bojong 1 Purbalingga" memperoleh hasil bahwa kelas yang 
menerapkan model pembelajaran kooperatif tipe Numbered Head Together memperoleh nilai rata-rata hasil belajar sebesar 79,90 berbeda dengan kelas yang tidak menerapkan model pembelajaran kooperatif Numbered Head Together memperoleh nilai rata-rata hasil belajar sebesar 70,53. Penelitian yang dilakukan Evan Nursaputra dan Romirio Torang Purba (2017) yang berjudul "Perbedaan Pembelajaran NHT dan TPS Ditinjau Dari Hasil Belajar Matematika Siswa Kelas 5 SD” di SDN 5 Boto, mendapatkan nilai rata-rata hasil belajar siswa yang menggunakan model pembelajaran Numbered Head Together sebesar 78,67, sedangkan nilai ratarata hasil belajar siswa yang menggunakan model pembelajaran Think Pair Share sebesar 73,00.

Dari hasil analisis penulis, dapat disimpulkan bahwa penggunaan model pembelajaran kooperatif tipe Numbered Head Together berpengaruh terhadap peningkatan hasil belajar siswa sekolah dasar, karena proses pembelajaran dalam model pembelajaran ini melibatkan siswa secara langsung sehingga siswa dapat berperan aktif dalam proses pembelajaran, serta siswa tidak akan mudah merasa bosan dan jenuh, dengan begitu pengaruh yang diberikan pada penggunaan model pembelajaran kooperatif tipe Numbered Head Together terhadap hasil belajar siswa dapat berpengaruh sangat tinggi terhadap hasil belajar siswa sekolah dasar. Peningkatan hasil belajar dari masing-masing penelitian juga berbeda, hal ini dapat dipengaruhi oleh beberapa faktor seperti faktor internal maupun faktor eksternal.

\section{KESIMPULAN}

Dari hasil penelitian meta-analisis model pembelajaran kooperatif tipe Numbered Head Together terhadap hasil belajar siswa sekolah dasar, penulis dapat menyimpulkan bahwa model pembelajaran kooperatif Numbered Head Together berpengaruh sangat tinggi terhadap peningkatan hasil belajar siswa sekolah dasar dari yang terendah 7,13\% sampai yang tertinggi $91,87 \%$ dengan rata-rata $37,11 \%$ dan dari penghitungan effect size diperoleh nilai sebesar 1,91, yang berarti dapat dikategorikan dalam interpretasi effect size bahwa penggunaan model pembelajaran kooperatif tipe Numbered Head Together berpengaruh peningkatan hasil belajar siswa sekolah dasar. Saran yang dapat disampaikan dari hasil penelitian ini yaitu diharapkan dalam penggunaan model pembelajaran kooperatif tipe Numbered Head Together dapat menjadikan dan menerapkan model pembelajaran kooperatif tipe Numbered Head Together sebagai model pembelajaran yang dapat mendorong siswa untuk memasuki zona nyamannya saat belajar di kelas sehingga siswa akan berperan aktif serta mendapatkan pengetahuan lebih banyak dengan saling bertukar ide satu sama lain, dengan begitu penggunaan model pembelajaran kooperatif tipe Numbered Head Together akan berpengaruh terhadap peningkatan hasil belajar siswa sekolah dasar, selanjutnya untuk guru dapat menggunakan model pembelajaran kooperatif tipe Numbered Head Together ini dalam pemilihan model pembelajaran untuk meningkatkan hasil belajar siswa. Hasil penelitian ini diharapkan dapat memberikan gambaran atau informasi bagi peneliti selanjutnya yang akan melakukan penelitian tentang penggunaan model pembelajaran kooperatif tipe Numbered Head Together dalam proses pembelajaran kemudian diharapkan dapat menggunakan lebih banyak artikel atau sumber lainnya yang relevan dengan memperketat penyeleksiannya serta diharapkan dalam pemilihan hasil penelitian yang akan digunakan dalam penelitian meta-analisis dapat memperhatikan metode dan metode statistik, dengan demikian dari penelitian metaanalisis akan memperoleh hasil yang lebih akurat.

\section{DAFTAR PUSTAKA}

Batubara, F., \& Sinulingga, K. (2014). Pengaruh Model Pembelajaran Kooperatif tipe Number Head Together terhadap hasil belajar siswa smp Pada materi getaran dan gelombang. INPAFI (Inovasi Pembelajaran Fisika).

Desy Nilam Sari, Suyitno Suyitno, I. L. (2018). KEEFEKTIFAN MODEL NUMBER HEAD TOGETHER 
445 Meta Analisis Model Pembelajaran Kooperatif Tipe Numbered Head Together Terhadap Hasil Belajar Siswa di Sekolah Dasar - Agape Purwa Gracia, Indri Anugraheni DOI: https://doi.org/10.31004/edukatif.v3i2.338

TERHADAP HASIL BELAJAR IPS KELAS III SD NEGERI DANYANGMULYO 02 KABUPATEN PATI. PROSIDING SEMINAR NASIONAL HIMA DAN PRODI PGSD 2017.

Evan Nursaputra, R. (2017). Perbedaan Pembelajaran Nht Dan Tps Ditinjau Dari. 5(2), 105-114.

Hamdayana, J. (2016). Metodologi pengajaran. Bumi Aksara.

Hanggara, A. H., \& Awang, I. S. (2016). Pengaruh Model Pembelajaran Numbered Heads Together terhadap Hasil Belajar. JURNAL PENDIDIKAN DASAR PERKHASA: Jurnal Penelitian Pendidikan Dasar, 8088.

Huda, M. (2013). Model-model Pengajaran dan Pembelajaran. Pustaka Pelajar.

I Md. Oka Susila, I Wyn. Rinda Suardika, I. W. S. uniasih. (2015). MODEL PEMBELAJARAN KOOPERATIF TIPE NHT BERBANTUAN MEDIA KONKRET BERPENGARUH TERHADAP HASIL BELAJAR MATEMATIKA SISWA KELAS V SD GUGUS VII KECAMATAN GIANYAR. E-Journal PGSD Universitas Pendidikan Ganesha, 3(1).

Isjoni. (2009). Cooperative Learning (Efektivitas Pembelajaran Kelompok). Alfabeta.

Jihad, A. dan A. H. (2012). Evaluasi Pembelajaran. Multi Pressindo.

Kirom, A. (2017). PERAN GURU DAN PESERTA DIDIK DALAM PROSES PEMBELAJARAN BERBASIS MULTIKULTURAL. Jurnal.Yudharta.Ac.Id, 3(1), 69-80.

Kristian, A. (2018). Pengaruh Model Pembelajaran Numbered Head Together ( Nht ) Terhadap Hasil Belajar Matematika Siswa Di Kelas Iv Sdn 4 Banda Aceh. GENTA MULIA: Jurnal Ilmiah Pendidikan, IX(2), $71-82$.

Mahardika, I. P. M., Dantes, N., \& Widiana, W. (2018). Pengaruh Model Pembelajaran Numbered Heads Together Terhadap Hasil Belajar IPS Pada Siswa Kelas V SD Gugus V Kintamani Tahun Pelajaran 2017/2018. MIMBAR PGSD Undiksha, 6(1), 1-32. ejournal.undiksha.ac.id

Popi Radyuli, Rini Sefriani, Nurul Qomariah. (2019). PEMBELAJARAN INQUIRY MENGGUNAKAN GOOGLE FORM TERHADAP HASIL BELAJAR SIMULASI DAN KOMUNIKASI DIGITAL. Edukatif Jurnal Ilmu Pendidikan, 1(2), 56-96.

Rizki, A. A. (2016). KEEFEKTIFAN MODEL NUMBERED HEAD TOGETHER DALAM PEMBELAJARAN IPS SISWA KELAS IV SDN 1 BOJONG PURBALINGGA.

Rofiq, M. N. (2010). Pembelajaran kooperatif (cooperative learning) dalam pengajaran pendidikan agama Islam. Jurnal Falasifa, 1-14.

Santiana, N. L. P. M., Sudana, D. N., \& Garminah, N. N. (2014). Pengaruh Model Pembelajaran Kooperatif Tipe Numbered Heads Together (NHT) Terhadap Hasil Belajar Matematika Siswa Kelas V Sekolah Dasar di Desa Alasangker. MIMBAR PGSD Undiksha.

Solihatin, E. dan R. (2008). Cooperative Learning Analisis Model Pembelajaran IPS. Bumi Aksara.

Sundari, H. (2015). Model-model pembelajaran dan pemerolehan bahasa kedua/asing. Jurnal Pujangga, 106117.

Suprihatiningrum, J. (2013). Strategi Pembelajaran Teori dan Aplikasi. AR-RUZZ Media.

Suryabrata, S. (2010). Psikologi Pendidikan. Raja Grafindo Persada.

Susanto, A. (2013). Teori Belajar dan Pembelajaran di Sekolah Dasar. Kencana Prenada media Group.

Trianto. (2010). Model Pembelajaran Terpadu Konsep, Strategi, dan Implementasinya dalam Kurikulum Tingkat Satuan Pendidikan(KTSP). Bumi Aksara.

Vivi Muliandari, P. T. (2019). Pengaruh Model Pembelajaran Kooperatif Tipe NHT (Numbered Head Together) Terhadap Hasil Belajar Matematika. International Journal of Elementary Education, 3(2), 132. https://doi.org/10.23887/ijee.v3i2.18517 
446 Meta Analisis Model Pembelajaran Kooperatif Tipe Numbered Head Together Terhadap Hasil Belajar Siswa di Sekolah Dasar - Agape Purwa Gracia, Indri Anugraheni DOI: https://doi.org/10.31004/edukatif.v3i2.338

Wasti, S. (2013). Hubungan Minat Belajar Dengan Hasil Belajar Mata Pelajaran Tata Busana Di Madrasah Aliyah Negeri 2 Padang. E-Journal Home Economic and Tourism. 